\title{
Mucins and NCAM (CD56) in intrahepatic cholangiocarcinogenesis
}

\section{As mucinas e o NCAM (CD56) na colangiocarcinogênese intra-bepática}

Anna Beatriz Telles Esperança'; Aline Helen da Silva Camacho²; Juliana Bigi Maya Monteiro³;

Geysa Bigi Maya Monteiro ${ }^{4}$; Adriana Caroli-Bottino5; Vera Lucia Nunes Pannain ${ }^{6}$

\begin{abstract}
Introduction: Cholangiocarcinoma is the second most common malignant neoplasm of the hepatobiliary system. During cholangiocarcinogenesis phenotypic changes occur in the ductal epithelium, including the expression of mucins (MUC). However, the evaluating studies of the expression of mucins in the different stages of cholangiocarcinogenesis are scarce. CD56 has also contributed in differentiating benign ductal proliferation and cholangiocarcinoma; however, its expression has not been evaluated in dysplastic epithelium of the bile duct yet. Objective: To assess immunohistochemical profile of (MUC) 1, 2, 5, 6, and CD56 in cholangiocarcinoma, pre-neoplastic and reactive lesions in the epithelium of intrahepatic bile ducts. Material and methods: Immunohistochemical expression of MUC 1, 2, 5, 6, and CD56 were studied for 11 cases of cholangiocarcinoma and 83 intrahepatic bile ducts (67 reactive and 16 dysplastic). Variables were considered significant when $p<0.05$. Results: The expression of MUC1 occurred in about $90 \%$ of the cholangiocarcinomas, contrasting with the low frequency of positive cases in reactive and dysplastic bile ducts $(\phi<0.001)$. However, there was no statistically significant difference in the expression of MUC5, MUC6 and CD56 between the reactive or dysplastic lesions and cholangiocarcinoma. The anti-MUC2 antibody was negative in all cases. Conclusions: MUC1 contributed for the differential diagnosis between cholangiocarcinoma and pre-neoplastic and reactive/regenerative lesions of intrahepatic bile ducts, and it should compose the antibodies panel aiming at improvement of these differential diagnoses. In contrast, MUC2, MUC5, MUC6 and CD56 were not promising in differentiating all the phases of cholangiocarcinogenesis.
\end{abstract}

Key words: cholangiocarcinoma; dysplasia; intrahepatic bile ducts; mucins; CD56.

\section{INTRODUCTION}

Cholangiocarcinoma (CC) is the second most common malignant neoplasm of the hepatobiliary system. In most cases there is no associated etiologic factor, however diseases such as primary sclerosing cholangitis (PSC), intrahepatic lithiasis (IHL), and Caroli's disease (CD) show a well-established relationship with this neoplasm ${ }^{(17)}$. CC pathogenesis is mainly related to chronic inflammation of the ductal epithelium, which is very common in the diseases mentioned above, with subsequent continuous proliferation and malignant transformation of its cells $s^{(13)}$. In cholangiocarcinoma, similarly to that observed in both bowel and gastric adenocarcinoma, the carcinogenesis process comprises from reactive and dysplastic changes in the epithelium to invasive cancer ${ }^{(1)}$. Besides the recognition of morphological changes that precede invasive cancer, recent studies reveal that during the cholangiocarcinogenesis process, molecular and phenotypic changes of the ductal epithelium occur ${ }^{(22)}$. During this process, some cells may continue expressing their specific subtype of mucin, however, changes in the original expression pattern frequently occur ${ }^{(6)}$.

Mucin (MUC) is a generic term used to refer to glycoproteins of high molecular weight, which can be found as structural components in most mucosal secretions that protect epithelial

First submission on 08/11/13; last submission on 07/12/13; accepted for publication on 24/02/14; published on 20/06/14

1. MSc in Medicine-Universidade Federal do Rio de Janeiro (UFRJ) (Medical Practitioner).

2. Pathology Medical Internship-UFRJ (Medical Practitioner).

3. Postgraduate Student in Anatomical Pathology-UFRJ.

4. PhD in Parasite Biology-Fundação Oswaldo Cruz (FIOCRUZ); professor at Universidade Severino Sombra.

5. PhD in Medicine-Ludwig-Maximilians Universität Müchen, Germany; associate professor of Department of Pathology of Medical School-UFRJ.

6. PhD in Medicine-UFRJ; full professor of Department of Pathology of Medical School-UFRJ. 
surfaces, as well as transmembrane proteins expressed on the apical surface of glandular and ductal structures of several organs ${ }^{(9)}$. Different kinds of mucins have been described in some cancers ${ }^{(2)}$. In bile ducts, mucin $5 / 6$ is more often expressed in dysplastic epithelium and CC than in the reactive epithelium ${ }^{(15)}$. In the other hand, MUC1 is observed in dysplastic epithelium and invasive $\mathrm{CC}$, and it is associated with the presence of metastasis, loss of differentiation, invasive growth, and lower survival rate ${ }^{(10,14,23)}$. However, there are still few studies that evaluate the expression of mucins in the different phases of cholangiocarcinogenesis.

The neuronal cell adhesion molecule (NCAM) CD56, has also contributed in differentiating benign proliferations (reactive ductules, focal nodular hyperplasia, and bile duct adenomas) and cholangiocarcinoma ${ }^{(5)}$. Nevertheless, its expression has still not been evaluated in dysplastic epithelium of the bile ducts.

\section{OBJECTIVES}

To assess the immunohistochemical profile of mucins 1,2,5, 6 , and CD56 in cholangiocarcinoma and in reactive and dysplastic lesions of intrahepatic bile ducts.

\section{MATERIAL AND METHODS}

11 CC cases and 83 of intrahepatic bile ducts, previously classified by Zen et al. ${ }^{(24)}$ as reactive (67) and dysplastic (16), were selected from files of Anatomical Pathology Service at Hospital Universitário Clementino Fraga Filho (HUCFF)Pathology Department/UFRJ. Among the dysplastic ones, biliary intraepithelial neoplasia ("BilIN") grades 1 and 2 were considered, which were assessed together, depending on the number of cases. Out of these, 11 patients had PSC, 11 had intrahepatic lithiasis, and 4 Caroli's disease. The selected cases were originated from surgical specimens of liver transplantation, lobectomy or segmentectomy.

Only the CC that showed immunoreactivity for CK $7 \geq 80 \%$ of tumor tissue were included in this study, while for CK20 and chromogranin A, a positivity $\leq 5 \%$ of the tumor surface was admitted. CC were classified as: well, moderately, and poorly differentiated, according to the $\mathrm{WHO}$ criteria $^{(12)}$.

Immunohistochemistry - All primary antibodies were originating from Novocastra, Newcastle/UK (Table 1). Novolink, Novocastra, Newcastle/UK, RE7140-CE detection system was used.
TABLE 1 - Primary antibodies

\begin{tabular}{ccccc}
\hline $\begin{array}{c}\text { Primary } \\
\text { antibody }\end{array}$ & Clone & Serum & Code & Dilution \\
\hline MUC1 & Ma695 & Mouse & NCL-MUC1 & $1: 200$ \\
MUC2 & Cc558 & Mouse & NCL-MUC2 & $1: 600$ \\
MUC5 & CLH2 & Mouse & NCL-MUC5AC & $1: 300$ \\
MUC6 & CLH5 & Mouse & NCL-MUC6 & $1: 300$ \\
CD56 (NCAM) & 1B6 & Mouse & NCL-CD56-1B6 & $1: 300$ \\
\hline
\end{tabular}

NCAM: neuronal cell adhesion molecule.

Criteria for evaluation of immunohistochemical reactions - reactions were considered positive when $>5 \%$ of cells showed cytoplasmic positivity for all antibodies used, except for the MUC1 which positivity was luminal and/or cytoplasmic, whereas CD56 was membrane antibody-positive.

Statistical analysis was performed using the $\mathrm{G}$ test, and the differences between variables were considered significant when $p<0.05$.

This study was approved by the Committee for Research in Medical Ethics-HUCFF/UFRJ, record CEP: 079/10.

\section{RESULTS}

The anti-MUC1 antibody was positive in 90\% of CC cases (2/2 well, $5 / 6$ moderately, and $3 / 3$ poorly differentiated), (Figure 1), contrasting with the low frequency of positive cases for the other diagnoses (reactive and dysplastic), which difference was statistically significant $p<0.001$ (Table 2). The anti-MUC2 antibody was negative in all cases regardless of diagnosis. Despite the higher percentage of positive staining for anti-MUC5 (Figure 2) and anti-MUC6 antibodies have been observed in dysplasia cases, this difference was not statistically significant in relation to positivity observed in the other diagnoses (Table 2). For anti-CD56 antibody expression (Figure 3), no significant differences in diagnoses expression were observed (Table 2).

TABLE 2 - MUC1, MUC5, MUC6, and CD56 antibody immunohistochemical expression

\begin{tabular}{lcccc}
\hline & MUC1 & MUC5 & MUC6 & CD56 \\
\hline Reactive epithelium & 5 & 27 & 8 & 13 \\
$(n=67)$ & $(7.5 \%)$ & $(40.3 \%)$ & $(11.9 \%)$ & $(19.4 \%)$ \\
Dysplastic epithelium & 1 & 10 & 5 & 3 \\
$(n=16)$ & $(6.3 \%)$ & $(62.5 \%)$ & $(31.3 \%)$ & $(18.8 \%)$ \\
CC & 10 & 6 & 2 & 3 \\
$(n=11)$ & $(90.9 \%)$ & $(54.5 \%)$ & $(18.2 \%)$ & $(27.3 \%)$ \\
$p$ value & $<0.001$ & 0.228 & 0.201 & 0.834 \\
\hline
\end{tabular}

CC: cholangiocarcinoma. 


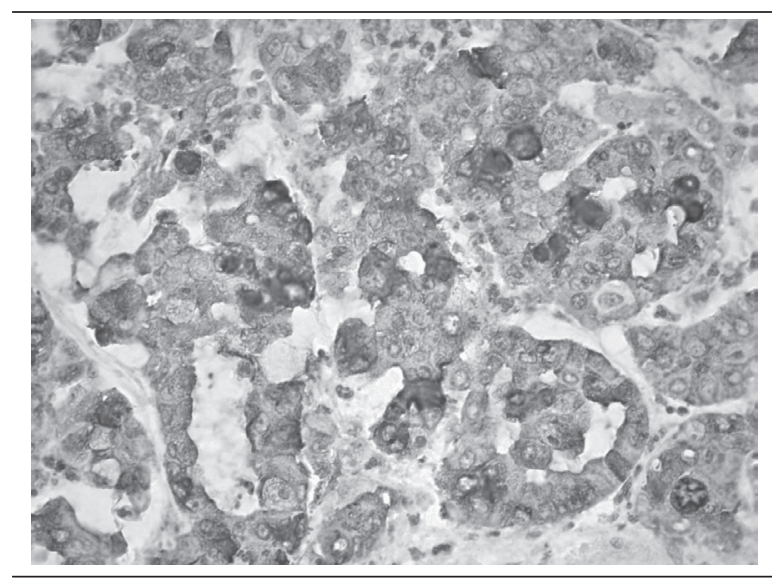

FIGURE 1 -Expression of MUC1 in cholangiocarcinoma

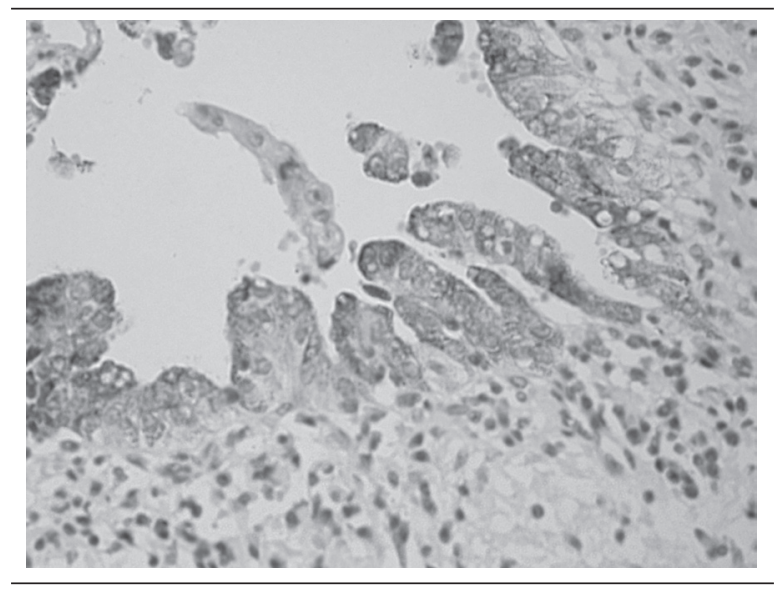

FIGURE 2 - Expression of MUC5 in dysplastic epithelium of intrahepatic bile ducts

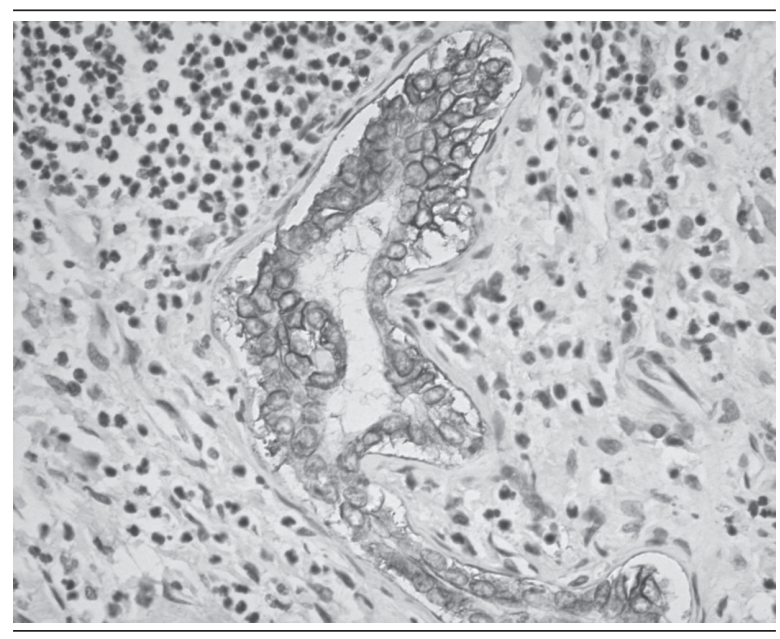

FIGURE 3 - Expression of CD56 in reactive epithelium of intrahepatic bile ducts

\section{DISCUSSION}

In this study, MUC1 was expressed in $90.9 \%$ of CC. This result is relevant because it is statistically significant $(\phi<0.001)$, when compared to reactive and dysplastic epithelial lesion of the bile ducts. In the biliary tract, the physiological expression of MUC1 occurs only in early fetal development ${ }^{(16)}$. However, this mucin may be expressed again in CC, as demonstrated in $97 \%$ of cases studied by Sasaki $e t$ al. ${ }^{(15)}$, this findings were also confirmed by other authors ${ }^{(1,22)}$. We also point out that this mucin was expressed in cholangiocarcinoma regardless of the degree of histological differentiation, contrary to that observed by other authors ${ }^{(10)}$, which showed lower expression in the well-differentiated CC. The few cases of well-differentiated CC in this study (2) were positive, but the sample size does not permit a comparative assessment with other results. Regarding the dysplastic epithelium, initial studies showed MUC1 luminal expression in 29\% of the studied lesions, when there was no standardization of morphological characterization of bile duct epithelial dysplasia ${ }^{(15)}$. In 2006, after the introduction of biliary intraepithelial neoplasia concept (BilIN), Zen et al. ${ }^{(23)}$ demonstrated MUC1 expression in $26 \%$ of Bilin cases, and lack of expression in normal biliary epithelium, reinforcing the evidence that there is increase of MUC1 expression during cholangiocarcinogenesis. Our results differ from the literature, because we observed only one dysplasia case that was MUC1 positive, among 16 cases (6.3\%). However, the authors mentioned above, have analyzed larger samples, respectively 24 dysplasia in Sasaki et al. ${ }^{(15)}$ study, and 38 Bilin in Zen et $a l .{ }^{(23)}$ study. In addition, the criteria used by Sasaki et al. ${ }^{(15)}$ to characterize dysplasia differ from those used in this study. Another factor that probably contributed to impair the comparison between results refers to the sample, since Zen et al. ${ }^{(23)}$ analyzed only large intrahepatic bile ducts in patients with IHL, while we evaluated septal and interlobular bile ducts of patients with PSC, IHL and Caroli's disease. We found 7.5\% of MUC1 expression in reactive lesions, contrasting with that observed by others ${ }^{(23)}$. Thus, we consider that this mucin was not useful for differentiating reactive and dysplastic lesions, although it has been very useful for the characterization of CC.

MUC2 was not expressed in any type of lesion, either reactive or neoplastic nature, although it has been demonstrated by other authors in intraductal papillary cystadenocarcinoma and cholangiocarcinoma of the biliary tract ${ }^{(18)}$. However, these studies presented a large numbers of extrahepatic or hilar CC cases $^{(10,14)}$, contrasting with this sample that was represented solely by intrahepatic nodules or masses. Nonetheless, Suh et al. have also described CC similar to those we studied, such as MUC1 positive and MUC2 negative ${ }^{(18)}$. The phenotypic variations observed in different CC sites in the biliary tract, probably derived from its origin in various progenitor cells ${ }^{(3)}$. Regarding to the reactive and dysplastic lesions, there are reports of positivity in about 29\% of the cases ${ }^{(15)}$. Again, the criteria for dysplasia characterization used by these 
authors differ from those used in this study, probably contributing to different results. Zen et al. . $^{(23)}$, also highlighted the use of MUC2 for the study of precursor lesions of the biliary epithelium, but with restricted expression to those related to morphological papillaryCC. We emphasize that this study was not designed in papillary preneoplastic lesions.

We found a higher expression of mucins 5 and 6 in dysplastic lesions, which were $62.5 \%$ positive for MUC5, followed by in $54.5 \%$ CC. MUC6 was positive in 31.3\% of dysplasias, and 18.2\% in CC. Several authors demonstrated higher expression of these mucins in both CC and dysplastic epithelium, emphasizing that they are important in characterizing biliary and pancreatic pre-neoplastic lesions $^{(7,11,15,20,21,24)}$. Although these results apparently substantiate the usefulness of mucins 5 and 6 in the characterization of preneoplastic lesions, we observed that both were also expressed in reactive epithelium in $40.3 \%$ and $11.9 \%$, respectively. Up to now, studies describing the expression of gastric mucins in reactive biliary epithelium were not found in the literature $(15,23,21)$. Thus, gastric mucin expression in the reactional epithelium of intrahepatic bile ducts, associated with the lack of statistical significance of dysplasia expression, points to a limited role of these mucins in distinguishing reactive and pre-neoplastic lesions.
The initial works of CD56 expression in biliary tract showed high percentages of positivity of this marker in proliferated bile ductules in cases of extrahepatic biliary atresia and other causes of cholestasis in pediatric patients ${ }^{(4,8,19)}$. Gütgemann et $a{ }^{\left({ }^{(14)}\right.}$ found expression in $70.5 \%$ of biliary adenomas and in $12.5 \%$ of CC, leading them to suggest that this marker would be useful to differentiate $\mathrm{CC}$ from other proliferative and ductal epithelium benign lesions. Our results do not support the usefulness of this antibody in differentiating malignant neoplasm (CC) of biliary precancerous and reactive lesions, since CD56 was expressed, with no statistically significant difference between them.

\section{CONCLUSION}

MUC1 have contributed in differentiating cholangiocarcinoma and pre-neoplastic and reactive lesions of intrahepatic bile ducts, and should compose the antibodies panel to be used aiming at the improvement of these differential diagnoses. In contrast, MUC2, MUC5, MUC6, and CD56 immunoexpressions were not promising in differentiating between the different stages of cholangiocarcinogenesis.

\section{RESUMO}

Introdução: O colangiocarcinoma é a segunda neoplasia maligna mais comum do sistema bepatobiliar. Durante a colangiocarcinogênese podem ocorrer alterações fenotípicas do epitélio ductal, incluindo a expressão de mucinas. Entretanto, os estudos que avaliam a expressão das mucinas nas diferentes etapas da colangiocarcinogênese são escassos. O CD56, apesar de contribuir na diferenciação entre as proliferações ductais benignas e o colangiocarcinoma, ainda não teve a sua expressão avaliada no epitélio displásico dos ductos biliares. Objetivos: Analisar o perfil das mucinas (MUC) 1, 2, 5, 6 e do CD56 no colangiocarcinoma, nas lesões pré-neoplásicas e reacionais de ductos biliares intra-hepáticos. Material e métodos: A expressão imuno-bistoquímica da MUC 1, 2, 5, 6 e do CD56 foram avaliadas em 11 colangiocarcinomas e 83 ductos biliares intra-hepáticos (67 reativos e 16 displásicos). As variáveis foram consideradas como significativas quando $\mathrm{p}<0,05$. Resultados: A expressão da MUC1 ocorreu em cerca de 90\% dos colangiocarcinomas, contrastando com a baixa frequência de casos positivos nos ductos biliares reativos ou displásicos ( $\mathrm{p}<0,001$ ). Não houve diferença estatisticamente significativa na expressão de MUC5, MUC6 e CD56 entre as lesões reativas, displásicas e o colangiocarcinoma. O anticorpo anti-MUC2 foi negativo em todos os casos. Conclusão: A MUC1 contribuiu no diagnóstico diferencial entre o colangiocarcinoma e as lesões pré-neoplásicas e reacionais/regenerativas dos ductos biliares intra-hepáticos, e deve compor o painel de anticorpos a ser empregado visando o aprimorando destes diagnósticos diferenciais. Contrariamente, a MUC2, MUC5, MUC6 e o CD56 não se mostraram promissoras na diferenciação entre as diferentes etapas da colangiocarcinogênese.

Unitermos: colangiocarcinoma; displasia; ductos biliares intra-bepáticos; mucinas; CD56. 


\section{REFERENCES}

1. BICKENBACH, K.; GALKA, E.; ROGGIN, K. K. Molecular mechanisms of cholangiocarcinogenesis: are biliary intraepithelial neoplasia and intraductal papillary neoplasm of the bile duct precursor to cholangiocarcinoma? Surg Oncol Clin N Am, v. 18, n. 2, p. 215-24, 2009.

2. BROCKHAUSEN I. Mucin-type 0-glycans in human colon and breast cancer: glycodynamics and functions. EMBO Rep, 2006, v. 7, n. 6, p.599604, 2006.

3. CARDINALE, V. et al. Mucin-producing cholangiocarcinoma might derive from biliary tree stem/progenitor cells located in peribiliary glands. Hepatology, v. 55, n. 6, p. 2041-42, 2012.

4. FABRIS, L. et al. Characterization and isolation of ductular cells coexpressing neural cell adhesion molecule and Bcl-2 from primary cholangiopaties and ductal plate malformation. Am J Surg Pathol, v. 156, n. 5, p. 1599-612, 2000.

5. GÜTGEMANN, I. et al. CD56 expression aids in the differential diagnosis of cholangiocarcinomas and benign cholangiocellular lesions. Virchows Arch, v. 448, n. 4, p. 407-11, 2006.

6. HO, S. B. et al. Heterogenity of mucin gene expression in normal and neoplastic tissues. Cancer Res, v. 53, n. 3, p. 641-51, 1993.

7. KIM, G. E. et al. Aberrant expression of MUC5AC and MUC6 gastric mucins and sialyl Tn antigen in intraepithelial neoplasms of the pancreas. Gastroenterology, v. 123, n. 4, p. 1052-60, 2002.

8. MAHJOUB, F. E. et al. CD56 staining in liver biopsies does not help in differentiating extrahepatic biliary atresia from other causes of neonatal cholestasis. Diagn Pathol, v. 3, n. 10, p. 1-5, 2008.

9. MALL, A. S. Analysis of mucins: role in laboratory findings. J Clin Pathol, v. 61, n. 9, p. 1.018-24, 2008.

10. MALL, A. S. et al. The expression of MUC in cholangiocarcinoma. Pathol Res Pract, v. 206, n.12, p. 805-09, 2010.

11. NAGATA, K. et al. Mucins expression profile in pancreatic cancer and the precursor lesions.J Hepatobiliary Pancreat Surg, v. 14, n. 3, p. $243-$ 54, 2007.

12. NAKANUMA, Y et al. Tumours of the liver and intrahepatic bile ducts. In: BOSMAN, FT. et al. WHO Classification of tumours of the digestive system. $4^{\mathrm{a}}$ ed. Lyon: IARC Press, 2010. Cap. 10; p. 195-262.

13. NAKANUMA, Y. et al. Anatomic and molecular pathology of intrahepatic cholangiocarcinoma.J Hepatobiliary Pancreat Surg, v. 10, n. 4, p. 265-81, 2003.
14. PARK, S. Y. et al. Expression of MUC1, MUC2, MUC5AC and MUC6 in cholagiocarcinoma: Prognostic impact. Oncol Rep, v. 22, n. 3, p. 649-57, 2009 .

15. SASAKI, M.; NAKANUMA Y.; KIM, Y. S. Characterization of apomucin expression in intrahepatic cholangiocarcinomas and their precursor lesions: an immunohistochemical study. Hepatology, v. 24, n. 5, p. 1.07478,1996 .

16. SAZAKI, M. et al. Biliary expression of MUC1, MUC2, MUC3 and MUC5/6 apomucins during intrahepatic bile ducts development and maturation: an immunohistochemical study. Am J Pathol, v. 147, n. 3 , p. 574-79, 1995.

17. SHIMONISHI, T.; SASAKI, M.; NAKANUMA, Y. Precancerous lesions of intrahepatic cholangiocarcinoma. J Hepatobiliary Pancreat Surg, v. 7 , n. 6, p. $542-50,2000$.

18. SUH, K. S. et al. Clinical outcomes and apomucin expression of intrahepatic cholangiocarcinoma according to gross morphology. J Am Coll Surg, v. 195, n. 6, p. 782-89, 2002

19. TORBENSON, M. et al. Bile duct and ductules are positive for CD56 (N-CAM) in most cases of extrahepatic biliary atresia. Am J Surg Pathol, v. 27, n. 11, p. 1.454-57, 2003.

20. YONEZAWA, S. et al. Precursor lesions of pancreatic cancer. Gut Liver, v. 2, n. 3, p. 137-54, 2008.

21. YONEZAWA, S. et al. Significance of mucin expression in pancreatobiliary neoplasms. J Hepatobiliary Pancreat Sci, v. 17, n. 2, p. 108-24, 2010.

22. YONEZAWA, S. et al. The expression of several types of mucin is related to the biological behavior of pancreatic neoplasms. J Hepatobiliary Pancreat Surg, v. 9, n. 3, p. 328-41, 2002.

23. ZEN, Y. et al. Biliary intraepithelial neoplasia: an international interobserver agreement study and proposal for diagnostic criteria. Mod Pathol, v. 20, n. 6, p. 701-09, 2007.

24. ZEN, Y. et al. Different expression patterns of mucin core proteins and cytokeratins during intrahepatic cholangiocarcinogenesis from biliary intraepithelial neoplasia and intraductal papillary neoplasm of the bile duct - an immunohistochemical study of 110 cases of hepatolithiasis. J Hepatol, v. 44, n. 2, p. 350-58, 2006.

\section{MAILING ADDRESS}

\section{Vera Lucia Pannain}

Universidade Federal do Rio de Janeiro, Faculdade de Medicina; Departamento de Patologia; Av. Prof. Rodolpho Paulo Rocco, 255; Cidade Universitária; CEP: 21941-913; Rio de Janeiro-RJ, Brazil; e-mail: verapannain@hotmail.com. 